\title{
FACTORS AFFECTING QUASI MONEY AFTER THE 1998 ECONOMIC CRISIS IN INDONESIA
}

\author{
Hastina Febriaty ${ }^{1}$, Octavianni Mardyanty Ritonga ${ }^{2}$ \\ Fakultas Ekonomi dan Bisnis, Program Studi Ekonomi Pembangunan \\ Universitas Muhammadiyah Sumatera Utara \\ hastinafebriaty@umsu.ac.id ${ }^{1}$, octaviannimardyantyritonga@gmail.com²
}

\begin{abstract}
This topic is raised based on the phenomenon occurring in the community that the high level of demand for quasi money in Indonesia, as well as the magnitude of the effect of gross domestic product (GDP), the exchange rate of rupiah, the inflation rate and the interest rate on demand for quasi money in Indonesia. By using OLS (Ordinary Least Square) method in E-views program 8. This research explains the influence of per capita income (GDP), rupiah exchange rate, inflation rate, and interest rate on quasi unag demand in Indonesia. With the type of Time Series research data collected for 17 years using secondary data from 2000-2016 taken from the Asian Development Bank and Bank Indonesia. From the results of research that has been done this research states that gross domestic product (GDP), exchange rate of rupiah, inflation rate and interest rate together have big influence to quasi money demand in Indonesia. In partial variable of Gross Domestic Product (GDP) positive and insignificant to quasi money in Indonesia, Rupiah Exchange rate has positive and significant influence to quasi money in Indonesia, Inflation variable has negative and insignificant influence and variable of Interest rate has negative and significant influence to quasi money in Indonesia.
\end{abstract}

\section{Keywords: Quasi Money, Gross Domestic Product, Rupiah Exchange Rate, Inflation Rate and Interest Rate.}

\section{INTRODUCTION}

Since the monetary crisis hit Indonesia in 1997 to 1998, the Indonesian economy has fallen and declined, as evidenced by the declining value of the rupiah against the US dollar, the economic crisis has also caused economic variables such as interest rates, inflation, exchange rates or exchange rates economic growth has sharply changed. Interest rates increased to $68.76 \%$ per year in 1998 , as well as inflation at that time increased by $77 \%$ per year (Indonesian Financial Statistics 1998).

In 1998 was the beginning of the collapse of Soeharto's leadership due to the crisis of public confidence in the government. The credibility crisis also hit financial institutions such as banks, the public rolled out massive money from banks, causing high money supply and inflation rates to rise dramatically.

This began with the crisis in Thailand, as the falling value of the bath currency after the Thai government was forced to float bath because at least the foreign exchange that can maintain anchor against the US dollar. At that time, Thailand borne the huge burden of foreign debt to the point that the country was declared bankrupt before the value of its currency fell. As the crisis spreads, currency crises in much of Southeast Asia and Japan come down, stock markets and asset values fall, and private debt rises dramatically. Indonesia, South Korea and Thailand are the worst affected countries.

Quasi-money demand in Indonesia occurs because saving money in the form of M1 is more risky while quasi money or M2 is more stable. The development of the money supply reflects the economic development. The economy grows and thrives causing the money supply to grow as well. If in the economy progresses, the portion of the use of currency (paper money and metal unag) is less, replaced by demand deposit. (Rahardja and Manurung, 2008: 324)

After the economic crisis that occurred in Indonesia since the recovery of Indonesian economy in 2000 quasi money demand continues to increase. This can be seen in the quasi money development table in Indonesia below. 


\begin{tabular}{|c|c|}
\hline Year & $\begin{array}{c}\text { The Development of Quasi Money } \\
\text { (Billion Rupiah) }\end{array}$ \\
\hline 2010 & 1.866 \\
\hline 2011 & 2.154 \\
\hline 2012 & 2.466 \\
\hline 2013 & 2.843 \\
\hline 2014 & 3.231 \\
\hline 2015 & 3.493 \\
\hline 2016 & 3.767 \\
\hline & Source: Asian Development Bank (www.adb.org) \\
\hline
\end{tabular}

Table 1 Quasi Money Development Table in Indonesia Year 2010-2016

Demand for quasi money continues to increase, although the increase is slow and not so high. The average growth that occurs from the year is only $1-2 \%$. The amount of quasi money in Indonesia is affected by several factors or variables such as gross domestic product or GDP per capita, inflation, exchange rate or exchange rate, and interest rate. National income or GDP per capita also influences the increase or decrease of quasi money in Indonesia. In general, per capita GDP affects quasi money in Indonesia, if per-capita GDP rises, consumption levels also rise. The higher the level of consumption, people prefer to spend their money this results in the money supply rises. An increase in the money supply also raises quasi money. Given this increase, it will cause inflation to rise and the economy overheating.

Based on the per capita GDP growth table, Inflation, KURS, and BI Rate above inconsistency with the development of quasi money. GDP per capita is relatively stable from 2000 to 2016 only the development rate is different, while inflation, exchange rate and bi rate continue to fluctuate, it shows that the inconsistency between quasi money with these variables.

The purpose of this research is to: To analyze the development of Quasi Money in Indonesia after the post-monetary crisis in 1998. Conduct an estimate of what factors affect the Quasi Money in Indonesia 2000-2016

\section{THEORETICAL BASIS}

According to Sadono Sukirno (2004: 267), money is created in the economy with the aim of expanding trade and exchange activities. Money is an inventory of assets that can be immediately used to make transactions. Money has three purposes: first as store of value, unit of account, and as medium of exchange. And the types of money are made up of fiat money, and commodity money. (N. Gregory Mankiw: 76).

Various kinds of money consists of currency that is money used as a means of legitimate transactions and must be accepted by all people in the economy. Currency is generally in the form of banknotes and coins made by Bank Indonesia as the central bank which is given the sole right of printing and circulating it. Deposits is a bill to commercial banks that can be used as a means of payment and legal transactions and people are not obliged to receive payment. Demand deposits can be spelled out easily, safely and practically because in doing transactions where a person does not have to count and bring a lot of cash. And money in the broad sense is called M2 because the money includes real money that is $\mathrm{M} 1+$ Balance of retail money market mutual funds + Savings deposits (including money market deposit accounts) + Small time deposits. (N. Gregory Mankiw: 2006)

Quasi money is part of the money supply consisting of rupiah and foreign exchange deposits owned by the population on a monetary system that temporarily loses its function as a medium of exchange. Quasi money consists of time deposits and people's savings in commercial banks, both in rupiah and in foreign currency (Manurung 2004:14). According to Bank Indonesia, quasi money consists of:

a. Time deposits and certificates of deposit, ie money lost for a while its function as a medium of exchange

b. Savings, ie money that is not completely liquid

c. Demand Deposit Account in foreign currency, ie assets that can fulfill its function as a medium of exchange but are accepted only in a limited environment 
d. Savings in foreign currencies, ie assets whose nature luquid lower than currency and demand deposits

According to N. Gregory Mankiw (2006: 19-26), Gross Domestic Product (GDP) is the market value of all final goods and services produced in the economy over a period of time. Economists and decision makers not only care about the total output of goods and services, but also this allocation among the various alternatives.

Foreign exchange rates or foreign exchange rates indicate the price or value of a country's currency is expressed in the currency of another country. The foreign exchange rate can also be defined as the amount of domestic money needed, ie the amount of rupiah required, to obtain a unit of foreign currency (Sadono Sukirno 2012:397).

According to the Central Bureau of Statistics of Indonesia, inflation is a tendency of rising prices of goods and services in general that continues on a continuous basis. If inflation rises, the price of goods and services in the country increases.

According to Bank Indonesia, the BI Rate is the policy rate reflecting the stance or monetary policy stance set by Bank Indonesia and announced to the public. The BI Rate is announced by the Board of Governors of Bank Indonesia at each monthly Board of Governors Meeting and implemented on monetary operations conducted by Bank Indonesia through liquidity management in the money market to achieve the operational targets of monetary policy.

In today's modern economy money in the broadest sense also known as quasi money is securities that can be used as a legal means of payment. Quasi money is money that cannot be used at any time in the payment due to the time constraints, namely time deposits and savings in rupiah and foreign exchange accounts of private domestic.

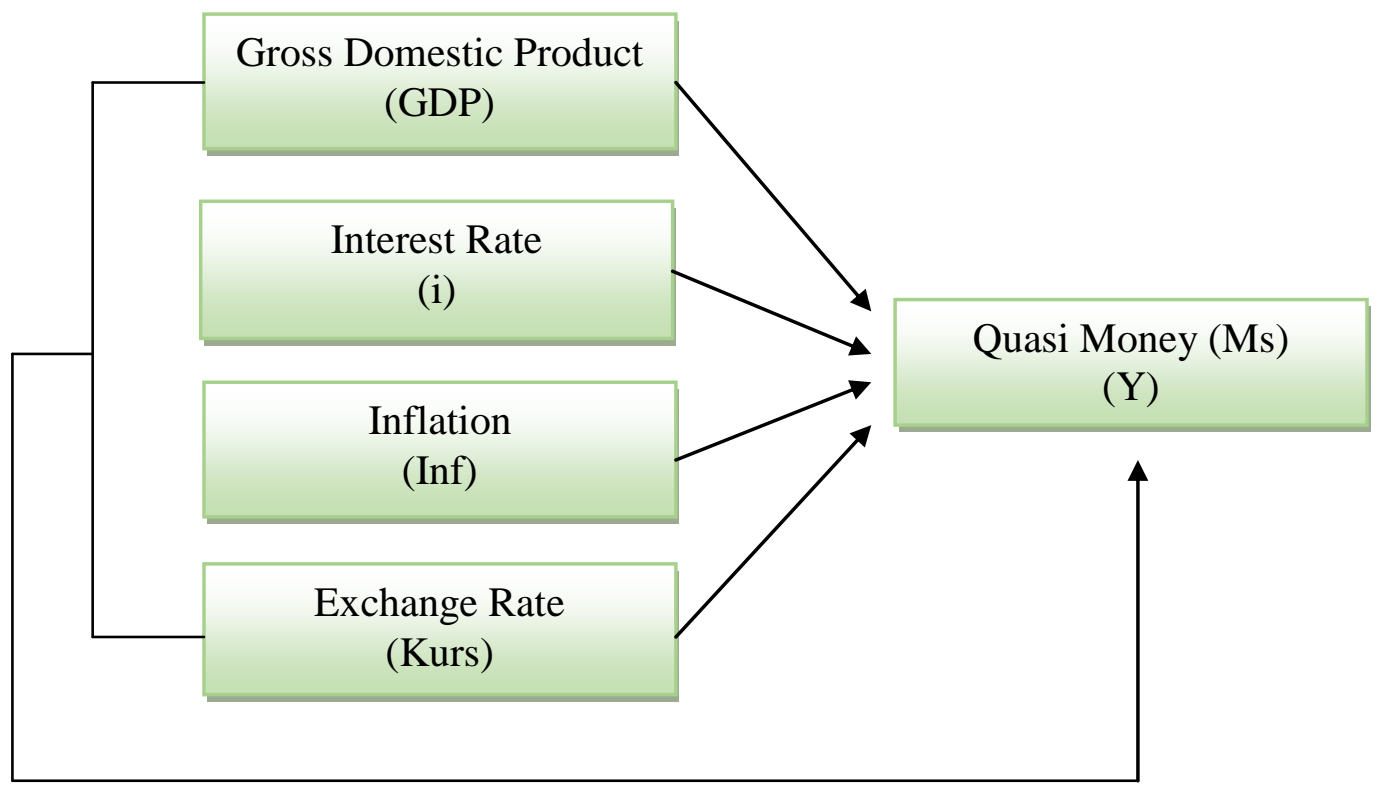

Figure 1. Conceptual Framework

After going through the above stages of theoretical studies and the results of previous empirical research and conceptual framework, the researcher made a provisional assumption (hypothesis) that the relationship between gross domestic product, interest rate, inflation and exchange rate or exchange rate influence quasi money in Indonesia.

\section{METHOD}

The data used in this research is secondary data that is data which usually have been collected by data collecting institution and published to public of data user, and presented in time series form, that is data arranged according to time in a certain variable. The data in this research is obtained from the 
publication of Bank Indonesia and Asian Development Bank in the form of annual data period 2000 2016. The variables to be observed are Quasi Money variables.

This research is done by using descriptive research method that is by giving exposure or explanation to the theories related to research title with method of quantitative approach. Quantitative research is the data obtained by measuring the value of one or more variables in a sample or population. Which aims to estimate and analyze the relationship between variables that have been determined to answer the problem formulation.

To identify the factors affecting the Quasi Money in Indonesia then analyzed by using Ordinary Least Square (OLS) method. As the effect of economic variables on Quasi Money, the econometric method is formulated as follows:

$\mathrm{Mst}=\beta 0+\beta 1 \mathrm{GDPt}+\beta 2 \mathrm{KURSt}+\beta 3 \mathrm{Inft}+\beta 4 \mathrm{it}+\varepsilon \mathrm{t}$

Where :

Ms $\quad$ = Dependent variable (quasi money variable)

$\beta 0 \quad=$ Intercept

$\beta 1, \beta 2, \beta 3, \beta 4, \beta 5=$ Free variable coefficients

GDP = Independent variable (dependent)

KURS $\quad=$ The rupiah exchange rate against the dollar (Rp / US \$)

Inf $\quad=$ Inflation $(\%)$

i $\quad=$ Interest Rate $(\%)$

$\varepsilon \quad \quad=$ Error term

\section{RESULT AND DISCUSSION}

\section{a. Classic Assumption Test}

\section{Multicolinearity Test}

This test aims to test whether the regression model there is a correlation between independent variables (independent). A good regression model requirement is that it should be free of multicolinearity. To see whether or not multicollinearity of the model can be done by looking at the Variance Inflation Factors table, as follows:
Variance Inflation Factors
Date: 03/15/18 Time: 19:44
Sample: 20002016
Included observations: 17

\begin{tabular}{cccc}
\hline \hline Variable & $\begin{array}{c}\text { Coefficient } \\
\text { Variance }\end{array}$ & $\begin{array}{c}\text { Uncentered } \\
\text { VIF }\end{array}$ & $\begin{array}{c}\text { Centered } \\
\text { VIF }\end{array}$ \\
\hline \hline C & 1797109. & 230.8303 & NA \\
GDP & 23290.24 & 85.01204 & 1.538823 \\
KURS & 0.003466 & 48.28361 & 1.163620 \\
Inf & 1519.109 & 11.71010 & 1.660958 \\
i & 1556.972 & 18.95607 & 2.292324 \\
\hline \hline
\end{tabular}

Table 2 Multicolinearity Test

Source: Data processed

From Table Variance Inflation Factors above can be seen that the value Centered VIF GDP 1.538823, KURS 1.163620, Inf 1.660958, and $\mathrm{r}$ 2.292324. Because the regression result of all independent variables (GDP), KURS, Inf, and I value $<10$ it is stated that in this model there is no multicollinearity problem. So this research is stated free from multicollinearity. 


\section{Heterocedasticity Test}

Heteroskedasticity Test: Breusch-Pagan-Godfrey

\begin{tabular}{llll}
\hline \hline F-statistic & 0.625734 & Prob. F(4,12) & 0.6532 \\
Obs*R-squared & 2.933881 & Prob. Chi-Square(4) & 0.5690 \\
Scaled explained SS & 1.382416 & Prob. Chi-Square(4) & 0.8472 \\
\hline \hline
\end{tabular}

Table 3 Heterocedasticity Test

Source: Data Processed

Because Heterocedasticity test with Breusch-Pagan-Godfrey test yields Prob value. Chi-square (4) in Obs * R-Squared of 0.5690 is greater than 5\% so this research is stated to be homokedastisitas or in other words this research is free from heterokedastisitas.

\section{Autocorrelation Test}

Breusch-Godfrey Serial Correlation LM Test:

\begin{tabular}{llll}
\hline \hline F-statistic & 1.458438 & Prob. F(2,10) & 0.2781 \\
Obs*R-squared & 3.838923 & Prob. Chi-Square(2) & 0.1467 \\
\hline \hline
\end{tabular}

\section{Table 4 Autocorrelation Test}

Source: Data Processed

Based on the result of Breusch-Godfrey Serial Correlation LM Test regression above Prob value. Chi-Square (2) in Obšk-squared of 0.1467 is greater than $5 \%$ then this research is free from autocorrelation problem. And by looking at statistical test Durbin Watson obtained value 1.989510 which means that the model used is free from autocorrelation problems.

Dependent Variable: MS

Method: Least Squares

Date: 03/12/18 Time: 21:03

Sample: 20002016

Included observations: 17

\begin{tabular}{crlrr}
\hline \hline \multicolumn{1}{c}{ Variable } & Coefficient & \multicolumn{1}{c}{ Std. Error } & t-Statistic & Prob. \\
\hline \hline C & -1895.681 & 1340.563 & -1.414093 & 0.1828 \\
GDP & 60.15697 & 152.6114 & 0.394184 & 0.7004 \\
KURS & 0.458463 & 0.058872 & 7.787478 & 0.0000 \\
Inf & -12.83952 & 38.97575 & -0.329423 & 0.7475 \\
\multicolumn{1}{c}{-143.5647} & 39.45848 & -3.638373 & 0.0034 \\
& 0.913631 & Mean dependent var & \\
R-squared & 0.884841 & S.D. dependent var & 1736.176 \\
Adjusted R-squared & 363.8022 & Akaike info criterion & 1072.054 \\
S.E. of regression & 1588224. & Schwarz criterion & 14.87103 \\
Sum squared resid & -121.4037 & Hannan-Quinn criter. & 15.11609 \\
Log likelihood & 31.73461 & Durbin-Watson stat & 14.89539 \\
F-statistic & 0.000003 & & 1.222550 \\
Prob(F-statistic) & & & \\
\hline \hline
\end{tabular}

Source : E-views 8 dan Data Processed

Tabel 5 OLS regression

From the data that has been obtained then the following regression equation and then will be analyzed by using Autokoregresi Model as follows:

$\hat{Y} t=-1895.681+60.15697 P D B t+0.458463 K U R S t-12.83952 I N F t-143.5647 S B t+\varepsilon t$ 
From the estimation results obtained can be made Testing Results Model or hypothesis taken through the results of this regression, namely:

\section{Test T Statistics or Partial Test}

\section{a. Gross Domestic Product (GDP)}

From the regression result, the coefficient value for the Gross Domestic Product (PDB) 60.15697 where the variable, has no significant effect on the Quasi Money in Indonesia. This is shown by thitung = 0.394184 and probability value 0.7004 (above $\alpha$ 5\%). This suggests that the relationship between Gross Domestic Product and Quasi Money in Indonesia is positive and insignificant. So it can be said that if the value of gross domestic product rose by $1 \%$ then Quasi Money increased by $60.15697 \%$.

\section{b. Exchange Rate (KURS)}

From the regression result, the coefficient value for the Rupiah exchange rate variable (KURS) is 0.458463 where that variable has a significant effect on the Quasi Money in Indonesia. This is indicated by the value of $t$ count $=7.787478$ and probability value 0.0000 (below $\alpha 5 \%$ ). This shows that the relationship between the Rupiah Exchange Rate (KURS) and Quasi Money is positive and significant. So it can be said that if the rupiah exchange rate rose by $1 \%$ then Quasi Money increased by $0.458463 \%$.

\section{c. Inflation Rate (Inf)}

From the regression result, the coefficient value for the Inflation (INF) variable is -12.83952 where that variable, has no significant effect on the Quasi Money in Indonesia. This is shown by thitung = 0.329423 and probability value 0.7475 (above $\alpha 5 \%$ ). This suggests that the relationship between Inflation (INF) and Quasi Money in Indonesia is negative and insignificant. So it can be said that if the value of inflation rose by $1 \%$ then Quasi Money decreased by $12.83952 \%$.

\section{d. Interest Rate (i)}

From result of regresi, coefficient value for variable of Interest Rate (SB) is -143.5647 where that variable, have significant influence to Quasi Money in Indonesia. This is shown by thitung = 3.638373 and probability value 0.0034 (below $\alpha 5 \%$ ). This shows that the relationship between the Interest Rate (SB) with Quasi Money in Indonesia is negative and significant. So it can be said that if the value of the interest rate rose by $1 \%$ then Quasi Money decreased by $143.5647 \%$.

\section{Test F (Simultaneous Test)}

F test is a simultaneous test of regression relationship that aims to determine whether all independent variables together have a significant influence on the dependent variable. Based on the above regression results obtained F-stastistik value of 31.73461 with probability value 0.000003 (below $\alpha 5 \%$ ). It shows that all independent variables (indevenden) together affect the dependent variable (devenden).

\section{RESULT}

\section{a. Gross Domestic Product (GDP)}

In this study based on the results of regression that has been done by the researcher shows that the variable of gross domestic product has a positive and insignificant relationship to quasi money in Indonesia. This is in line with the research conducted by Damayanti (2010) in his research entitled Analysis of Economic Variables Affecting the Money Supply in Indonesia is the variable of gross domestic product has a positive and insignificant relationship to quasi money in Indonesia. In the long run, gross domestic product has a positive and insignificant effect on quasi money because of the instability between government policy and economic growth. However, unlike research conducted by Yulimar (2015) in his research entitled Quasi Money Quot Analysis in Indonesia Period 2000-2014 which says that the variable of gross domestic product has a positive and significant influence to quasi money in Indonesia. 


\section{b. Rupiah Exchange Rate (Kurs)}

In this study based on regression results that have been done by the researcher shows that the variable of rupiah exchange rate has positive and significant relation to quasi money in Indonesia. This is in line with research conducted by Damayanti (2010) in his research entitled Analysis of Economic Variables Affecting the Money Supply in Indonesia and Yulimar (2015) in his research entitled Quasi Money Quot Analysis in Indonesia Period 2000-2014 namely the variable exchange rate of rupiah has a positive and significant relationship to quasi money in Indonesia. This indicates the weakening of the balance of payments due to soaring world oil prices and the crisis in the US as well as the demand for foreign exchange to meet the needs of imports and servicing of external debt. The addition of the US dollar amount will increase the international reserves and the amount of quasi money (money supply).

\section{c. Inflation (Inf)}

In this study based on the results of the regression that has been done by the researcher shows that the inflation variable has a negative and insignificant relationship to quasi money in Indonesia. This is in line with research conducted by Damayanti (2010) in his research entitled Analysis of Economic Variables Affecting the Money Supply in Indonesia and Yulimar (2015) in his research entitled Quasi Money Analysis Analysis In Indonesia Period 2000-2014 ie the inflation variable has a relationship that positive and insignificant to quasi money in Indonesia. Inflationary variables do have a positive effect on quasi money but are not significant, this is due to the drop in export performance and the government has not been able to stabilize prices, especially food commodity prices and prices in transportation, communication and financial services groups.

\section{d. Interest Rate (i)}

In this study based on the results of regression that has been done by the researcher shows that the variable interest rate has a negative and significant relationship to quasi money in Indonesia. This is in line with the research conducted by Damayanti (2010) in his research entitled Analysis of Economic Variables Affecting the Money Supply in Indonesia is the variable interest rates have a negative and significant relationship to quasi money in Indonesia. Because in the long run when low interest rates people would prefer to hold money instead of buying bonds, people would feel that the yield of the interest rate is not attractive enough. But unlike the research conducted by Yulimar who said that the variable interest rates have a negative and insignificant effect on quasi money in Indonesia. According to Yulimar (2015) in his research entitled Analysis Query Money Demand in Indonesia Period 20002014 this is because the economic actors do not anticipate changes in the money supply in the same period but in the next period. And also commercial banks have not been able to perform their duties as an intermediary institution that channeled third party funds when the crisis occurred.

\section{CONCLUSION}

From research on the factors affecting Quasi Money after the 1998 economic crisis in Indonesia can be drawn the following conclusions:

Based on regression / model estimation influential GDP, KURS, INF, and SB is worth 0.913631 or $91.4 \%$ which means have a very strong relationship between independent variables with dependent variable. In other words, the rise and fall of quasi unag rates will depend on all independent variables, namely, gross domestic product, rupiah exchange rate, inflation and interest rates. This model has the remaining \&t (Error term) of $8.6 \%$ which of these results is probably explained by other variables not included in this estimation model.

Factors affecting Quasi Money in Indonesia are gross domestic product (GDP), exchange rate of rupiah (KURS), inflation (INF), and interest rate (SB) have significant effect. Partially, the variable of gross domestic product (GDP) positive and not significant to quasi money in Indonesia, rupiah exchange rate variable (KURS) have positive and significant influence to quasi money in Indonesia, inflation variable (INF) have negative effect and not significant and variable interest rate (SB) have negative and significant influence to quasi money in Indonesia. Together GDP, KURS, INF, and SB have a large influence on demand for Quasi Money in Indonesia. 


\section{REFERENCE}

Aditya Novianto, 2011. Analisis Pengaruh Nilai Tukar (Kurs) Dolar Amerika/Rupiah (Us\$/Rp), Tingkat Suku Bunga Sbi, Inflasi, Dan Jumlah Uang Beredar (M2) Terhadap Indeks Harga Saham Gabungan (Ihsg) Di Bursa Efek Indonesia (Bei) Periode 1999.12010.6 (Skripsi). Semarang: Universitas Diponegoro.

Arifianto, Doddy. Moch, 2012. Ekonometrika. Jakarta: Erlangga

Asian Development Bank, 2000-2016. Data Jumlah Uang Kuasi, Inflasi, Jumlah Uang Beredar, Produk Domestik Bruto Perkapita. Www.Adb.Org. Di Akses Pada [10 Januari 2018].

Bank Indonesia, 2000-2016. Data Suku Bunga Bi. Www.Bi.Go.Id. Di Akses Pada [12 Januari 2018].

Gujarati, N. Damodar Dan Dawn C. Porter, 2010. Dasar-Dasar Ekonometrika Edisi 5. Jakarta: Salemba Empat

Mankiw, Gregory. N., 2006. Makroekonomi Edisi Keenam. Jakarta: Erlangga

Miskhin, S. Frederic, 2009. Ekonomi Uang, Perbankan, Dan Pasar Keuangan Edisi 8. Jakarta: Salemba Empat

Nachrowi, Djalal. Nachrowi, 2008. Penggunaan Teknik Ekonomertika. Jakarta: Pt Raja Grafindo Persada

Pohan, Aulia, 2008. Potret Kebijakan Moneter Indonesia Edisi 1. Jakarta: Pt Raja Grafindo Persada

Safitri Damayanti, 2010. Analisis Variabel Ekonomi Yang Mempengaruhi Jumlah Uang Beredar Di Indonesia (Skripsi). Jakarta: Universitas Islam Negeri Syarif Hidayatullah.

Samuelson, A. Paul Dan William D. Nordhaus, 2001. Ilmu Makroekonomi Edisi 17. Jakarta: Pt Media Global Edukasi

Sukirno, Sadono, 2012. Makroekonomi Modern. Jakarta: Pt Raja Grafindo

Sukirno, Sadono, 2012. Makroekonomi Teori Pengantar Edisi Ketiga. Jakarta: Rajawali Pers

Yulimar, 2015. Analisis Permintaan Uang Kuasi Di Indonesia Periode 2000-2014 (Skripsi). Pekan Baru : Universitas Riau 